\title{
IF THE ‘SCHU’ FITS: TRANSLATING A MOMENT OF SONG IN PROUST’S LE
}

TEMPS RETROUVÉ

In September 2018, I went to Durham to give a paper at a conference on sound. ${ }^{1}$ I had written a paper about Marcel Proust and the German composer Robert Schumann, and since the conference was not limited to French studies, I wanted to provide English translations of the quotations I was using. Turning to the most recent translation of Proust into English, that published by Penguin in 2002 and edited by Christopher Prendergast, I searched for the word 'Schumann' in a digital library copy. To my surprise, the passage I was looking for did not come up. Cursing the vagaries of electronic search functions, I began skim-reading the volume in question: Finding Time Again, the final volume of Proust's In Search of Lost Time, translated by Ian Patterson. ${ }^{2}$ Eventually I found the sought-after lines, lines which comment on Robert de Saint-Loup's last words to the protagonist before returning to death on the front line. Here I came up short, for a reason I relate below.

\section{The Final Meeting with Saint-Loup}

The moment is a poignant one, told as a flashback (or what Genettians would call an analepsis) immediately on having been informed of Saint-Loup's death. Here we have in crystalline form the personality of a character whom one critic has endearingly compared to the 'Petit Prince': aristocratic, golden-haired, and generous-spirited. ${ }^{3}$ It is this generosity which is brought to the fore in this final encounter between the two friends, and which functions not only on an interpersonal level, but also on a wider, political scale. The narrator records how Saint-Loup — although fighting, and eventually dying, for the French — hates neither the Germans nor German culture, hence his bursting into a song by Schumann in German. The protagonist, in contrast, is much more petty-minded. Generally prone to 
condemning friendship as a waste of time, in this specific instance he proves himself, besides, to be mindful more of what the neighbours might think than of the preciousness of this lyrical exchange, and so cruelly silences what will subsequently prove to be Saint-Loup's last words to him:

les derniers mots que j'avais entendus sortir de sa bouche, il y avait six jours, c'étaient ceux qui commencent un lied de Schumann et que sur mon escalier il me fredonnait, en allemand, si bien qu'à cause des voisins je l'avais fait taire. ${ }^{4}$

Here is not the place for a closer analysis of this passage, which invites us to consider wider French attitudes towards German music around the time of the First World War. ${ }^{5}$ Rather, what interests me chiefly is how a small error in translation can afford a new look at this passage. Let us, therefore, return to the Penguin translation via the briefest of considerations of the translation history of Proust's novel. ${ }^{6}$

\section{Proust's English Translators}

The first to attempt to translate Proust's novel into English was Proust's rough contemporary, C. K. Scott Moncrieff. Legend has it that Moncrieff translated Proust in isolation in his Scottish castle, but subscribing to this popular image is to forget Moncrieff's military engagement and work as a spy, not to mention the fact that he translated authors other than Proust (including works by writers as different as Stendhal and Luigi Pirandello). ${ }^{7}$ Proust himself lamented the

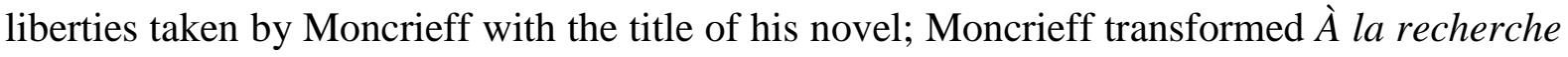
du temps perdu into Remembrance of Things Past, a phrase borrowed from one of Shakespeare's sonnets. ${ }^{8}$ Further problems arise with this translation given both the editorial state of Proust's novel at the time and Moncrieff's own death in 1930, leaving the project 
unfinished. Consequently, later translators have sought to complete Moncrieff's work. The final volume of Proust's novel was translated, in turn, by Stephen Hudson — Sydney Schiff's alias — in 1931, by Frederick A. Blossom in 1932, and by Andreas Mayor in 1970. Moncrieff's text has also undergone a series of revisions, first by Terence Kilmartin (1981), then by D. J. Enright (1992), and most recently in William Carter's ongoing project (2013-) to produce a revised, annotated version for an American market.

Against this already crowded translational hinterland, the Penguin translation (2002) aims to provide a new readable version produced by another team of translators (one per volume), based on the latest edition of the original text. Amidst the debates that have inevitably ensued, I am pointing out a striking error in Patterson's translation not in order to criticize this translation, but rather in order to suggest that this error is usefully revealing. The error might, then, be understood as a sort of Freudian slip, although my approach is indebted more immediately to Adam Watt's analysis of the role of reading in Proust's novel, and draws particular strength from the following observation: 'So complex are its effects that any reading, however "wrong-headed", has its measure of profit. In Proust mistakes tend to be as instructive and beneficial as things done "correctly". ${ }^{9}$ My reading of one particular mistake in translation, below, is entirely concordant with this view, and rests on a broader belief that translation studies might benefit significantly from Watt's Proustian insight. There would, I think, be much to be gained from shifting the terms of debates around errors in translation in such a direction.

\section{An Eloquent Error}

Here, finally, is the passage in Patterson's translation: 
the last words I had heard him utter, six days earlier, were the opening words of a Schubert song which he had been singing in German on my staircase, so enthusiastically that I had to tell him to stop because of the neighbours. ${ }^{10}$

Evidently, in this passage Schumann has been replaced with Schubert. This error is peculiar to Patterson; earlier translators had correctly written Schumann. What interests me, however, is not the source of the error - whether translator, editor, copy-editor, typesetter, proofreader, or a combination of any or all of these — but rather its consequences. As such, I consider this error to be one of translation, understood as a complex and collaborative process of publication, and not one that necessarily pertains to the individual translator. My approach is pragmatic, concerned with the practical repercussions of the error, although such an approach also has theoretical implications for the way we understand and respond to such errors.

What, then, are the consequences of this particular error? On the one hand, it seems likely that German song, for non-specialists, is more closely associated nowadays with Schubert than with Schumann. Thus, this slip (to whosoever it belongs) is potentially indicative of the reception of lieder and the status of both Schubert and Schumann amongst recent Anglophone readers. ${ }^{11}$ Indeed, the replacement might even be justified from this perspective on the grounds of a domesticating, reader-focused translation approach. ${ }^{12}$ On the other hand, the error also makes the informed reader reflect on why it matters that Saint-Loup is singing a Schumann and not a Schubert song. Again, at stake is what the two composers each represent: for Proust in the first instance; perhaps for Patterson too (though the responsibility may equally, as I have said, lie elsewhere in the process); and ultimately for Proust's readers, faced with the original and/or the translated text. 
Moreover, for readers of Patterson's Proust alone, it is simply a fact that Saint-Loup does embark on a song by Schubert. In this light, I admit to finding the choice of Schubert both fitting and tempting, not only because Schubert might add a gay subtext to this exchange, but more importantly because we could then describe Saint-Loup's last words as his Schwanengesang, his swansong. ${ }^{13}$ It would also be pleasingly symmetrical that Proust's protagonist had himself sung 'l'Adieu de Schubert' (ALR II, 666) as he renounced his love for Saint-Loup's aunt, the duchesse de Guermantes, in a much earlier volume. Yet this last reference should give us pause, since the composer of this song has been shown to be not Schubert but rather August Heinrich von Weyrauch. ${ }^{14}$ Moreover, the lines that Proust cites in French from this song (and which enable its identification) are not accurately quoted. ${ }^{15}$ In short: Proust and Patterson both misattribute a key moment of song to Schubert rather than to another composer; Proust's Schubert, whether in the original or in translation, is frequently pseudonymous; matters of translation lead both author and translator into deviation from the original. From this perspective, Patterson has, ironically, very much caught the spirit, if not the letter, of Proust's novel.

\section{Last Words}

Patterson's translation of Schumann as Schubert is a singular detail that likely becomes negligible on consideration of the bigger picture. Yet I have suggested that it is worth reflecting on this detail not in order to point fingers or call out error, but rather in order to enjoy the moment as a sort of thought experiment. There are evident and undeniable problems with erasing Schumann from the final encounter between the protagonist and SaintLoup, not least the fact that Proust shows a predilection for Schumann rather than Schubert and cites the former much more than the latter in the Recherche itself. ${ }^{16}$ Notwithstanding, it is productively disorientating to read this passage in Patterson's translation from the perspective 
of an English reader not familiar with the original — in other words, to ask: what if SaintLoup had sung a song by Schubert rather than by Schumann? This question leads us to the realm of the counterfactual, which is a pleasant place in which to sojourn temporarily, as the editor of the Penguin translation would no doubt agree. ${ }^{17}$ From this holiday in the land of possibility, taken at Patterson's unwitting invitation, we gain a new appreciation of one moment of song in Proust's Recherche. This appreciation is inevitably individual, as it depends upon our familiarity with and comparative attachment to the songs of Schumann and Schubert. Our responses are not, however, insignificant just because they are rooted in our individual memories and affections, and therefore difficult to generalize or quantify critically. Ultimately, moreover, this unique example in the history of translations of Proust points to new ways of approaching certain (but certainly not all) errors in translation, that is, from the point of view of plurality, defamiliarization, and possibility. This type of reading may be a form of 'délire' — to return to Watt's notion of productive misreadings in Proust ${ }^{18}$ — but it is a 'délire' for which histories and theories of translation might profitably make more space.

1 'Symposium of Sound', Durham University, 3-4 September 2018. More details at the conference website: https://symposiumofsound.wordpress.com/ [accessed 13 November 2018].

2 Marcel Proust, Finding Time Again, ed. by Christopher Prendergast, trans. by Ian Patterson (London: Penguin, 2002).

3 Brigitte Mahuzier, Proust et la guerre (Paris: Honoré Champion, 2014), p. 114. 
4 Marcel Proust, À la recherche du temps perdu, ed. by Jean-Yves Tadié, 4 vols (Paris: Gallimard, 1987-89), IV, 425. This edition is subsequently abbreviated to ALR.

5 The best politicized discussion of this passage is Jérôme Cornette, ““...un lied de Schumann": The Politics and Aesthetics of Singing', trans. by Jane Kuntz, in Proust in Perspective: Visions and Revisions, ed. by Armine Kotin Mortimer and Katherine Kolb (Urbana: University of Illinois Press, 2002), pp. 254-70.

6 For further discussion of the history of Proust's translation into English, see: Christopher Prendergast, 'General Editor's Preface', in Marcel Proust, The Way by Swann's, ed. by Christopher Prendergast, trans. by Lydia Davis (London: Penguin, 2002), pp. vii-xxi; Michael Wood, 'Translations', in Marcel Proust in Context, ed. by Adam Watt (Cambridge: Cambridge University Press, 2013), pp. 230-40; Son et traduction dans l'œuvre de Proust, ed. by Emily Eells and Naomi Toth (Paris: Honoré Champion, 2018).

7 See the account of Moncrieff's life by his great-grand-niece Jean Findlay, Chasing Lost Time: The Life of C. K. Scott Moncrieff, Soldier, Spy and Translator (London: Chatto \& Windus, 2014).

8 See Marcel Proust, Correspondance, ed. by Philip Kolb, 21 vols (Paris: Plon, 1970-93), XXI, 499-500 (letter 343 to Scott Moncrieff [le 9 ou 10 octobre 1922]). 
9 Adam Watt, Reading in Proust's 'À la recherche': 'le délire de la lecture' (Oxford: Clarendon Press, 2009), p. 15. See also Sigmund Freud, The Psychopathology of Everyday Life, ed. by James Strachey, trans. by Alan Tyson (London: Ernest Benn, 1966).

10 Proust, Finding Time Again, trans. Patterson, p. 155. It is surprising that this error was not spotted by the general editor of this translation, since he himself discusses the importance of the choice of Schumann in his own book on Proust, albeit without directly citing from Patterson's translation at this juncture: see Prendergast, Mirages and Mad Beliefs: Proust the Skeptic (Princeton: Princeton University Press, 2013), pp. 207-09. Another loss in the translation of this short passage is the rendition of the verb 'fredonner' as 'singing', although arguably this smoothes over a paradox that otherwise remains in the original: what does it mean to hum in German? After all, the initial mention of 'les derniers mots' (my emphasis) and the subsequent detail of 'il me fredonnait, en allemand' surely suggests Saint-Loup's song has some words, and the neighbours, moreover, must be expected to recognize and react to hearing German, rather than simply to hearing the wordless, hummed melody of a German composer. I leave the necessary review of Proust's use of the verb 'fredonner' across the Recherche to another occasion.

11 On the modern Anglo-American reception of lieder, see most recently Laura Tunbridge, Singing in the Age of Anxiety: Lieder Performances in New York and London between the World Wars (Chicago: University of Chicago Press, 2018).

12 For this terminology, see Lawrence Venuti, The Translator's Invisibility: A History of Translation, 2nd edn (London: Routledge, 2008), although Venuti critiques such an approach. 
13 On the question of Schubert's sexuality and its relevance for an understanding of his music, see amongst others Lawrence Kramer, Franz Schubert: Sexuality, Subjectivity, Song (Cambridge: Cambridge University Press, 1998).

14 This correction is already in the notes to the Pléiade edition (ALR II, 1720).

15 For further discussion, see Jennifer Rushworth, 'Proust, Hahn, and the Art of Song', in 'Swann' at 100/'Swann' à 100 ans, ed. by Adam Watt (= Marcel Proust Aujourd'hui, 12 (2015)), pp. 168-83.

16 Proust lists Schumann as one of his favourite composers in the questionnaire 'Marcel Proust par lui-même', in Proust, Contre Sainte-Beuve; précédé de Pastiches et mélanges; et suivi de Essais et articles, ed. by Pierre Clarac with Yves Sandre (Paris: Gallimard, 1971), pp. 336-37 (p. 337). Schumann is also the subject of an early poem by Proust: see 'Portraits de musiciens: Chopin, Gluck, Schumann, Mozart', in Proust, Jean Santeuil précédé de Les Plaisirs et les jours, ed. by Pierre Clarac with Yves Sandre (Paris: Gallimard, 1971), pp. 8284 (p. 83).

17 See Christopher Prendergast, Counterfactuals: Paths of the Might Have Been (London: Bloomsbury, forthcoming 2019).

18 The pun on 'délire' is present from the subtitle of Watt's book, 'le délire de la lecture', onwards. 